\title{
Are the New EU Member States Prepared for the Flexicurity System?
}

\author{
Vida Sruk ${ }^{1}$, Dejan Romih $^{2}$ and Mejra Festić*,3 \\ ${ }^{I}$ Faculty of Economics and Business, University of Maribor, Slovenia \\ ${ }^{2}$ Faculty of Economics and Business, University of Maribor; EIPF - Economic Institute of the Law School, Ljubljana. \\ slovenia \\ ${ }^{3}$ Faculty of Economics and Business, University of Maribor; EIPF - Economic Institute of the Law School, Ljubljana. \\ Slovenia
}

\begin{abstract}
Social policy and labour market policy in the EU are facing a challenge to regulate a dynamic labour market in the context of the globalised economy. The New Member States are seeking more stability and security in order to encourage employers to invest more in human capital to be able to boost productivity and competitiveness. Countries need to promote more flexibility and adaptability for both - enterprises and workers, and to better balance them with security. Flexicurity system contributed to higher employment and also to higher mobility between unemployment and employment labour force in some west European economies. Attitudes, values and tradition of certain economy are preconditions for successfulness of the flexicurity system.
\end{abstract}

Keywords: flexicurity, labour market, ethics, religion.

JEL: A14, J23, J31, J48, O15.

\section{INTRODUCTION}

During the process of integration in the European monetary integrations, NMS have to gradually give up a part of their own monetary sovereignty, and abandon it completely when entering the EMU. Entering the European monetary union requires that the loss of independent monetary policy is substituted by other economic policies. Asymmetric shocks represent a problem in the common European monetary union, where the monetary policy is unable to work. Taking into account the fact that fiscal policy does not always represent a suitable instrument for taking actions, asymmetrical shocks at certain market rigidity can be neutralised only with increased capital and work mobility and a more flexible labour market.

Experience of Western European countries related to the labour market flexibility point to different strengths and weaknesses. During the period of favourable economic conditions, ageing of the population and ensuring high level of social security, during which academic and political circles believed that social economy cannot cope with structural changes and demands regarding increased labour market flexibility, increased interest among NMS for the model of flexicurity has been noticed.

The topic of this article is the interpretation - in an interdisciplinary way, economically and sociologically - of the influence of different religions or convictions related to religious values on work and general creativity of people, i.e. on economic life. In our contribution, we try to answer the question if efficient combination of flexible labour market and employment security is possible in NMS and to explain the notion of flexicurity.

*Address correspondence to this author at the Faculty of Economics and Business, University of Maribor; EIPF - Economic Institute of the Law School, Ljubljana. Slovenia; E-mail: mejra.festic@uni-mb.si; mejra.festic@eipf.si

\section{THE INFLUENCE OF RELIGION ON ECONOMY AND WORK}

Various religious groups, particular churches or denominations, large groups (nations, classes) or small groups and their everyday working and religious activities are discussed. The issue under discussion is further complicated by various circumstances, above all substantial differences in individual's faith, oscillations regarding the tendency for secularism and desecularism, suppression of religious institutions and pressures on believers, the presence of different forms of atheism and agnosticism, negative events in religious institutions, etc.

During the past 150 years, a substantial amount of religious, cultural, sociological, sociopsychological and socioantropological literature appeared dealing with the problems of economic life. In the above-mentioned interdisciplinary set of questions moral and ethical questions play an important role, because economic life and religious issues always bring to the fore various moral problems and values, such as diligence and laziness, honesty and dishonesty, moderation and immoderation, etc. In addition, we may deal with basic, fundamental sociological issues, with essential sociohistorical and socioeconomical processes. One of the best examples for such paradigmatic social interpretation is Max Weber's The protestant ethic and the spirit of capitalism (1904,1905).

After several decades of studying Weber's research of religious life and capitalist economy in the work stated above and other Weber's works, it has become obvious to what extent he was wrong and what is his contribution towards the comprehension of the above issues. Here, we have to point out the prevailing motive for his enthusiasm about this segment of sociology of ideas. Above all, he wanted to find a thorough explanation of the significance of the abovementioned relationship for the whole social, economic and cultural life of the West, i.e. the most developed societies in 
the Western Europe. His interest focused on the problem of the material, social and spiritual specificity of this socially, culturally and intellectually most developed part of the world.

Weber discovered the fundamental general feature of the Western society in the concept of rationalization. According to Weber, the whole Western culture is controlled by processes of rationalisation, reason: our everyday existential activities and relationships, our common sense, scientific and philosophical thinking, economy, politics, etc. Through rationalism, individuals increasingly control their reality.

Other civilisations have also experienced substantial progress, including theological and philosophical, related to natural sciences, important partial organisational and productive achievements, as well as huge power and wealth concentrations of sovereigns. But only Western civilisation realised capitalism in the sense of rational organisation of formally free labour, which definitely separates enterprises from home production, with completely developed rational accounting, which ensures lasting profitability to its owner-entrepreneur (Pavićević, 1980, 112).

The above-mentioned features of European culture and capitalist economy should be explained simultaneously from two opposite points of view: from the point of view of economic factors and from the point of view of existential, spiritual, cultural viewpoints or positions of individuals. If rational capitalist business activities are to take place, certain adequate way of life and the ideology of economic rationality has to be established first. Weber found out that the main dynamic factor, which stimulates the development of rational capitalist economy is protestant religion of Calvinist type (his attitude toward Lutherans was rather indifferent), in particular its economic ethic.

Above all, we should bear in mind that Weber's integrated concept of capitalism represents a wide framework for the topic under discussion. Weber was interested in capitalism in the same way as he was interested in developmental historical process, or in developed economic system, and theoretical forecast of its future (Weber, 1968, 283).

Weber saw the importance of internal, immanent or subjective side of capitalist production. The Spirit of Capitalism, which represents, according to Weber, above all an emphasised positive observation of economic activity and maximum profitability, was completely separated from traditional economy. Weber thus expresses a view that capitalistic organisation of economy as an economic system cannot be thought of without certain notional elements (Đurić, 1964, 112). In summary, the spirit of capitalism belongs to the very essence of existence and modern capitalism. It is not just a reflection, a conceptual or spiritual reflex of the materialistic basis of social life, but an independent factor, i.e. a force with its own existence. Weber wanted to find out why the spirit of capitalism appeared only in the Western civilisation. Above all he wanted to discover to what extent and how this phenomenon shaped modern capitalistic society.

Weber did not doubt that Protestantism represented economic, political and moral basis for capitalism. The main historical event: Reformation movement in 16th and 17th century, which introduced ascetic Protestantism in reformed Calvinist church, and later in other churches (ibidem, 113).
Askasis of the initial capitalist accumulation. Asceticism as frugality, as accumulation of capital, as exceedingly rational "economisation", which opposes all forms of sybaritic behaviour and lavish hedonism. Today, such capitalism, tagged with the asceticism, does not exist anymore. For the enormous increase in production and the explosion of false human needs in developed capitalism, consumerism is most suitable form. Believers, agnostics or atheists should become homo consumens, people, who are not particularly workaholic, creative, motivated and successful, but consumeroriented. Asceticism is for those who do not have, for people in the domain of poverty.

Weber compared economic success and socioeconomic initiative of protestant countries with Southern catholic countries. He believed that protestant ethos is superior and more successful in terms of work, creativity and business activities. There was a fundamental change, a turning point related to people, believers. Marx defined this change in his own way, in the spirit of historical materialism: "Luther certainly defeated subservience arising from piousness, because he substituted it with subservience arising from conviction. He defeated the faith in authority, because he restored the authority of religion. Priests became laymen, because laymen became priests. He liberated men of external piousness, because he made faith reside within humans. The body was emancipated from fetters, because people's hearts were shackled." (Marx and Engels, 1969, 201) It can be believed that Marx's sharp dialectic paradoxes partly influenced Weber's thinking about the decisive role of Protestantism on the rise of capitalism.

Weber did not think only in terms of the positive effects of protestant ethical doctrine on the one side, and the less supportive Catholic and Orthodox ethics on the other side, but in terms of immanent personal position, people's attitude towards work, towards creativity, frugality and other relevant economic features. In summary, he spoke about uniquely articulated practical point-of-view, which, in different religions and in certain broader social environments, influenced on work motivation and general productivity of people. Different religions in their moral/theological and socioethical conceptions deal with work, creativity and economic behaviour in rather different ways, which influences the life and behaviour of believers. In general terms it is possible to ascertain that some of these concepts are more workrelated, productive and motivating, practical in its secular everyday meaning, whereas others favours passive attitudes and contemplative spirituality.

When more than a hundred years ago Weber contemplated about the agreement of Protestant ethic with the spirit of capitalism, he noticed that Catholicism tended to be less effective in this relationship and function - maybe it even represented an obstacle due to something which was poetically dubbed by a Slovenian moral theologian Vladimir K. Truhlar half a century later with "feudalism in our blood". Tuhlar wrote about authoritarianism, conservatism, dogmatism and other relics of feudal ideology and mentality within the Church and believers (Truhlar, 1967, 58 -59). Based on the study carried out in 1910 by Martin Offenbacher (Konfession und soziale Schichtung. Eine Studie über die wirtschaftliche Lage der Katholiken und Protestanten in Baden) Weber found out that there is a huge difference in 
motivation, commitment at work, aspirations and consequently economic efficiency of the two leading religions. Catholics belonging mainly to the rural social class were rarely keen on acquiring additional education; if they found employment in industry they were seldom promoted. Protestants were highly attracted vocational training, they climbed the corporate ladder and often took leading managerial positions. They were extremely entrepreneurial, which Catholics usually lacked. On the other hand, Protestants prospered and achieved enviable financial positions (Hamilton, 2000, 152).

It is neither reasonable nor justifiable to claim that only some religions demand from their believers and from people in general that they are highly committed to work and that they possess economic and material or cultural virtues. Such direct explanation would be wrong, despite the fact that the Catholic social doctrine emphasizes and interprets these issues in more detail than, say, the Orthodox doctrine. All religions, directly or indirectly encourage people to work. Ora et labora is a generally accepted slogan, except perhaps in an eccentric sect, and the most important mechanisms of work ethics are usually indirect.

With regard to the relationship of Catholicism towards work and working class, social and economic problems, it is necessary to point out the importance of the Catholic social doctrine that addressed the condition of the working class in 1891, when Pope Leo XIII. passed the encyclical "Rerum Novarum", and the endeavours of the Roman Catholic Church today. It is also necessary to point to the Second Ecumenical Council of the Vatican, which represented a change in understanding and valuing work, where work is valued above nature and capital. The actual man represents work, he works, produces - he is a man with his freedom and openness in the Absolute. A complete contrast to such work of a personally free man is represented by a worker, who is enslaved with his work, alienated and depersonalised. The work process should be adapted to the needs of individuals, to their existential characteristics and abilities. Worker's personal life should also be taken into. Employees should have enough free time for leisure activities, cultural events, rest and spiritual life. Employees must have the right to preserve dignity. In addition, employees should have the opportunity to develop skills and talents, even if they are not demanded by his present position at work (Truhlar, 1967, 5455). Pope John XXIII. and the Council draw attention to work as the key social value, materialised through hard work by the working class, which is often exploited and abused. A huge hierarchical institution may find it hard to implement the humane ands progressive ideas of Blessed John XXIII.

The Orthodox Church participates in the spirit of capitalism even less frequently as the Catholic Church during the time of Weber's research. European West has been trying to impose its religious, cultural and social-ethical models to the Orthodox Church. On the other hand, in the $20^{\text {th }}$ century Orthodox churches experienced extremely fierce political and ideological pressure from the part of authoritarian communist Leninist and Stalinist dictatorship.

Western churches are not ready to establish a dialogue with the Slavic Orthodox Church, which led to its reluctance to globalisation that is favoured in the West. Because of this Orthodox Church cannot get rid of its deep distrust towards the Western religions and are thus unwilling to open to the necessary modernisation (Kovačič Peršin et. al, 2005, 5-6). The content of such modernisation is related social, socioeconomic, cultural, political and ethical concepts. European integrations are carried out according to the principles of globalisation, neoliberalism, capitalism and multicultural paradigm, which threatens special national identities. The Orthodox religion is not keen on such European modernisation, mainly due to the fact that, after the dissolution of the USSR and after the fall of the communism Russia and some other Orthodox countries experienced unforeseeable neoliberal crisis, which result existential insecurity of people. If Russian employees were exploited by etatistic and bureaucratic caste in the past, they are, at present, exploited by private capitalists, who are descendants of the before mentioned Soviet elite. In Russia, the proverb saying that it is very far up to God and much further up to the Tsar still holds true.

In Eastern and South-Eastern Europe, some Islamic ethnic groups also exist. Despite the fact that Islamic countries lagged behind the Christian West in terms of socioeconomic and cultural and political development, this can not be simply attributed to the Islamic religion. Historically, Islam in the European East and Near East was inferior to the Western Islam (Caliphate of Cordoba). In addition, in recent history Muslims living in the European east and South-East, with the exception of those living in Turkey, were subject to decades of oppression, both cultural and spiritual, which had a certain influence on their attitude towards work and creativity ${ }^{1}$.

The most important message of this document is that Islamic society should take responsibility for the mobilisation of human and natural resources, with certain measures that should promote hard work and creativity. Survival or demise, strength and weaknesses of Islamic society depend on the same conditions and rules that guide all other nations and societies. Two widely spread illusions should be eliminated: naive belief in redemptive miracles and the help from strangers. Wealth cannot be brought into the country, but must be created with labour. Only a conscious, involved and active Islamic community, ready to accept the challenges and risks, can find itself and the right path (Izetbegović, 1990, 16, 34 -35). Muslims should be critical both to modernism and conservatism. Modernism frequently offers uncritical foreign models of society; conservatism often dogmatically keeps with historically outdated positions.

\section{LABOUR MARKET FLEXICURITY EU}

There are two different approaches to flexicurity. The first approach includes flexibilisation of the whole work force and includes the majority of employees with typical working contracts. Flexibilisation can be implemented in two ways, either through new ways of organising work or through different, more diverse working time arrangements. At the same time, flexibilisation should be accompanied with some forms of employment security. In this respect, Denmark is a well-known example. It combines relaxed employment protection with a high level of employment benefits for the unemployed and active labour market policies. In doing this, the security component is ensured by the Gov-

\footnotetext{
${ }^{1}$ A characteristic contemporary reaction of Islamic believers against such oppression and lagging behind other nations is represented by the document, which declared emancipation of Islam in Bosnia and Herzegovina in the early seventies of the $20^{\text {th }}$ century.
} 
ernment and not by the employers. Worker protection and not job protection is in the forefront (Vermeylen and Hurley 2007). Austria also focused on this component, when it codified severance payments, which are transferable and not linked to one employer.

The second approach includes the normalisation of the rights of employees with atypical working contracts (parttime employment, different forms of temporary employment, and fixed-term employment), without reducing the flexibility of such contracts. The same idea will be implemented in the Netherlands through increased social security of the employees with atypical employment contracts and through the unification of their rights with those of full-time workers. Trade unions in Slovenia are also in favour of equal rights for workers on part-time employment contracts and those on full-time contracts (taking loans, education, pension rights, etc.).

There are huge differences regarding the proportion of atypical workers among the EU-15 states. In some countries have very high shares. Both the United Kingdom and the Netherlands have high percentage of part-time work, whereas Spain has a high percentage of fixed-term contracts. $30 \%$ of the entire workforce in Spain represents employees on fixed-term contracts. Recent labour market reforms in Spain have attempted to redress some of the disadvantages associated with previous reforms, which aimed at the flexibilisation of the labour market. Excessive labour market segmentation and declining levels of per head productivity presented a huge problem (Vermeylen and Hurley 2007). The purpose of recent reforms was to increase security and rights of workers with atypical workers and to create incentives for employers to convert atypical to typical contracts.

\subsection{Labour Market Flexicurity EU Member States}

During the time of favourable economic conditions and high level of social security, during which academic and political circles believed that social economy cannot cope with structural changes and demands regarding increased labour market flexibility, increased interest among the majority of European countries for the Danish model of flexicurity has been noticed (Auer and Cazes 2000).

In Denmark, the balance between employment flexibility and social security is maintained by social policy, unemployment benefits, loose collective agreements, a lower degree of centralisation and with the decentralised negotiations between social partners, as well as with the help from inter- nal labour market and setting up of small enterprises (Andersen and Svarer 2005). Similarly, high level of social security is also a characteristic of the Swedish labour market, whereas the flexibility of Swedish labour market is considerably lower. This is mainly the consequence of low trust among social partners, but the situation in this area has improved considerably. Denmark belongs to countries with the lowest job security, which is nevertheless higher than in Switzerland, Canada, Great Britain and the United States.

In the Netherlands, the emphasis is on employment security and not job security. In this respect, negotiations between social partners and part-time employment play an important role. Belgium and Germany have high flexibility in their internal labour markets, whereas Denmark and the Netherlands have high flexibility in their external labour markets. Unlike the Netherlands, Germany and Belgium have more traditional forms of flexibility, emphasising internal numerical flexibility and job security (see Table $\mathbf{1}$ ).

Belgium, Luxemburg and Portugal developed a system, which ensures high employment security. The same holds true for Spain and Ireland, where employment security is slightly lower. In Spain, security and flexibility are differentiated with regard to different groups of employees, which is a consequence of a dual labour market. On one labour market employees are highly protected, whereas on the other they are much less protected, which leads to a higher flexibility of this labour market. In the United Kingdom the model of liberal labour market prevails, which enables easier and quicker promotion and thus leads to greater employment security. In Great Britain, Portugal and Luxemburg the time to convert atypical employment to typical is the shortest.

There are different forms of labour market flexibility: (i) external numerical flexibility, (ii) internal numerical flexibility, (iii) functional flexibility, (iv) labour cost/wage flexibility and (v) externalisational flexibility. With regard to security we differ between: (i) job security, (ii) employment security, (iii) income security and (iv) combination security (Wilthagen 2002), (see Table 2).

\section{Denmark}

By changing labour legislation in 1978, Denmark eliminated restrictions regarding the length of period, during which the unemployed receive unemployment compensations and at the same time introduced subsidised employment of the long-term unemployed in private sector (Madsen 1999). Later, a change in legislation followed, allowing peo-

Table 1. EU States with Regard to Predominant Flexicurity Type

\begin{tabular}{|c|c|c|c|c|}
\hline & Job security & Employment security & Income security & Combination security \\
\hline \hline External numerical flexibility & Spain & The Netherlands, Denmark & $\begin{array}{c}\text { CEE countries (EU member } \\
\text { states) }\end{array}$ & Austria \\
\hline Internal numerical flexibility & Belgium, Germany, Austria & The Netherlands, Spain & Germany & Finland \\
\hline Functional flexibility & Germany, Portugal & Italy, Latvia & Denmark & \\
\hline Labour cost/wage flexibility & Portugal, Austria & & & \\
\hline Externalisational flexibility & & & & \\
\hline
\end{tabular}

Source: Wilthagen and Tros (2004), Wilthagen and van Velzen (2005). 
Table 2. Flexicurity Matrix

\begin{tabular}{|c|c|c|c|c|}
\hline Security/flexibility & $\begin{array}{l}\text { Job security (protection } \\
\text { against lay-offs and consid- } \\
\text { erable changes regarding } \\
\text { working conditions) }\end{array}$ & $\begin{array}{l}\text { Employment security } \\
\text { (availability of suitable } \\
\text { jobs) }\end{array}$ & $\begin{array}{l}\text { Income security (ensured } \\
\text { minimal benefits when } \\
\text { unemployed) }\end{array}$ & $\begin{array}{l}\text { Combination security (a } \\
\text { combination of afore- } \\
\text { mentioned formsa of secu- } \\
\text { rity) }\end{array}$ \\
\hline $\begin{array}{l}\text { External numerical flexibil- } \\
\text { ity (flexibility regarding } \\
\text { employment and laying-off) }\end{array}$ & $\begin{array}{l}\text { Types of employment con- } \\
\text { tracts } \\
\text { Employment protection } \\
\text { legislation } \\
\text { Early retirement }\end{array}$ & $\begin{array}{l}\text { Employment services } \\
\text { /active labour market policy } \\
\text { training/life-long learning }\end{array}$ & $\begin{array}{l}\text { unemployment compensa- } \\
\text { tions } \\
\text { other social benefits } \\
\text { minimum wages }\end{array}$ & $\begin{array}{l}\text { protection against dismissal } \\
\text { during various leave } \\
\text { schemes }\end{array}$ \\
\hline $\begin{array}{l}\text { Internal numerical flexibil- } \\
\text { ity (flexibility regarding } \\
\text { working hours) }\end{array}$ & $\begin{array}{l}\text { shortened work/week /part- } \\
\text { time employment }\end{array}$ & $\begin{array}{l}\text { employment protection } \\
\text { legislation } \\
\text { training/life-long learning }\end{array}$ & $\begin{array}{l}\text { part-time supplementary } \\
\text { benefit } \\
\text { study grants } \\
\text { sickness benefits (e.g. due } \\
\text { to sickness or injuries) }\end{array}$ & $\begin{array}{l}\text { different kind of leave } \\
\text { schemes } \\
\text { part-time pension }\end{array}$ \\
\hline $\begin{array}{l}\text { Functional flexibility (job } \\
\text { rotations with regard to } \\
\text { different jobs and types of } \\
\text { work) }\end{array}$ & $\begin{array}{l}\text { »multitasking } \\
\text { training } \\
\text { labour leasing } \\
\text { subcontracting } \\
\text { »outsourcing « }\end{array}$ & $\begin{array}{l}\text { training/life-long learning } \\
\text { job rotation } \\
\text { teamwork }\end{array}$ & $\begin{array}{l}\text { performance related pay } \\
\text { systems }\end{array}$ & $\begin{array}{l}\text { voluntary working time } \\
\text { arrangements }\end{array}$ \\
\hline $\begin{array}{l}\text { Labour cost/ wage flexibil- } \\
\text { ity (adjustments regarding } \\
\text { wages according to per- } \\
\text { formance of employees and } \\
\text { companies) }\end{array}$ & $\begin{array}{l}\text { local adjustment in labour } \\
\text { cost } \\
\text { scaling/reductions in social } \\
\text { security payments }\end{array}$ & $\begin{array}{l}\text { changes in social security } \\
\text { payments } \\
\text { employment subsidies } \\
\text { in-work benefits }\end{array}$ & $\begin{array}{l}\text { collective wage agreements } \\
\text { benefit for shortened work } \\
\text { week }\end{array}$ & $\begin{array}{l}\text { voluntary working time } \\
\text { arrangements }\end{array}$ \\
\hline $\begin{array}{l}\text { Externalisational flexibility } \\
\text { (employment without em- } \\
\text { ployment contracts, through } \\
\text { employment agencies) }\end{array}$ & & & & \\
\hline
\end{tabular}

Source: Vermeylen and Hurley (2007) and author's amendments.

ple over 60 a quasi-retirement, during which they received unemployment compensation. This measure caused a retreat of skilled workforce from the labour market. Legislation amendments followed in the period between 1993 and 1994, whereas in 1996 the period during which the unemployed were eligible for unemployment compensation were shortened from 7 to 5 years. In 1999, it was further shortened to four years (Madsen 2002b).

Danish model differs between several types of flexibility and security with regard to the level (national, regional, local and entrepreneurial) and with regard to formal layout (legislation, collective and individual negotiations). The model follows the guidelines which help individual's to cope with social risks and participate in public-private partnerships (Wilthagen and Tross 2004).

Internal and external numerical flexibility enable structural adjustment of the economy to the conditions on the world market, lowering labour costs and introducing technological innovations, which contribute towards the creation of new jobs. On the other hand, the flexibility of working time contributed towards the increase in the number of the employed who work over time (Madsen 2002b).

In Denmark, there is low employment security and high labour force fluctuation. Every year, $25 \%$ of employees change their jobs (Vermeylen and Hurley 2007). This share is slightly higher in young workers. In Denmark, there are (according to data from 2004) $91 \%$ of employees, who signed full-time contracts, atypical employment contracts are not so frequent (Breggard et al. 2005).

Unemployment funds represent a distinctive feature of the Danish model. The funds are organised as private funds. There are 34 funds for employees and 2 employer funds. The membership is voluntary, but nevertheless more than $85 \%$ of employees are members of such funds. The first such fund was established in Denmark towards the end of 19th century. Funds are financed by subsidies and memberships. Unemployment compensations paid by funds can amount to $90 \%$ of last salary, but cannot exceed $1700 €$ (data for 2004).

\section{The Netherlands}

Rigid social policy and relatively high employment security contributed to the increase in the number of unemployed during the 80 s of the 20th century. Labour market reforms followed, with the purpose to increase employment flexibility with simultaneous maintenance of social security. During the period between 1999 and 2003, the share of part-time contracts increased, work from home, through agencies and other types of atypical work. 
Changes in legislation regarding probationary period, which cannot exceed two months, followed. Temporary contracts can only be signed for the period of two years, parttime contracts for the period of three years. Employers can sign part-time contracts with employees only three times in a row, the subsequent contract has to be signed for full-time employment. Derogations are possible with regard to current collective agreements and arrangements (van Oorshot 2001).

During the recession, employers are allowed to lay off employees, until the situation in the company has improved. The employer has the right to offer part-time employment to the worker waiting for employment. Minimum wage and working hours have been determined for such cases. Unemployment compensations are ensured for workers who are willing to accept less paid jobs (Clasen et al. 2001). In the Netherlands, according to legislation, the rights of workers with atypical jobs have been the same as the rights of fulltime workers.

\section{Germany}

In 2002, Germany carried out reforms of the labour market. With Hartz I they established employment agencies for part-time jobs, with the main purpose to encourage the unemployed to find employment, and to help companies find suitable work force and subsidise employment. In Germany, they changed legislation, because they had strict legislation regarding dismissal. This led to the increase in the number of part-time employment contracts, because employers were hiring workers through employment agencies and were thus receiving employment subsidies. Hartz II followed and changed employment agencies into employment centres. They introduced »mini jobs « for low skill workers, who were exempt from paying personal income tax and »midi jobs « for high skill workers, for which employers had to pay social security benefits. In 2004 and 2005 there have been some positive effects of the labour market reform, because the amount of undeclared work decreased (Seifert et al. 2005). Hartz III followed, which simplified the employment and subsidies procedures. Hartz IV contributed towards the increase of active job seeking. According to this legislation, people who have not been previously employed were eligible for unemployment benefits. Benefits I are granted to the unemployed for the period of 1 year, benefits II were granted to those, who are not eligible for benefits I, if they disclose their property. In February 2006, the period during which the unemployed were eligible for benefits was shortened to 18 months for the elderly and at the same time introduced the possibility of their part-time employment. The fourth law contributed towards the increase of the number of unemployed, because the job-seeker register included also those who had been receiving social benefits and were not actively seeking employment.

\subsection{Flexicurity in NMS-12}

After 1990, NMS-12 were faced with the decrease of the number of employed and increased long-term unemployment. Employment trends moved from large state-owned companies to small and medium-sized private enterprises and from primary and secondary to tertiary and quarter sectors.

In their efforts to adapt their labour markets, Slovenia and the Check Republic were among the most successful
NMS countries (and also Slovakia). They succeeded in lowering the unemployment rate to one digit level, and at the same time retain high level of work activity. The reason for this is likely to lie in more favourable economic structure and efficient labour market policy (Lubyova and Ours 1999).

Due to less favourable economic structure labour market adaptation in Poland lasted for a longer period of time than in other NMS. The reason for this lies in ineffective labour market policy. Kluwe, Lehmann and Schmidt (1999) found out that the long-term labour market policy was efficient enough, but the efficiency of various employment programmes aimed at the improvement of professional worker mobility was hindered by market inconsistencies. Boeri and Flinn (1999) for example, found out that low level of employing unemployed persons was the consequence of segregation of those who had been once employed in the public sector, because it was difficult for them to get employment in the private sector. An important reason for a slower labour market adaptation can also be found in too low percentage of gross domestic product for financing active labour market policy. Poland had, similarly as Slovenia, introduced the programme of public works, with the purpose to improve full-time employment opportunities for the unemployed. The Slovene programme differed from the Polish programme in that it ensured jobs in education and culture also for more educated unemployed workers.

Among the NMS, Poland has highest degree of unemployment and second lowest degree of work activity. Only Hungary has a lower degree of work activity. Low professional and spatial mobility of workers can partly be explained by the increase in the number of unemployed workers and agricultural subsidies (Boeri and Flinn 1999).

The Check Republic implemented both active and passive labour market policy. Its active labour market policy was carried out in local employment offices. Within the framework of this policy, it also implemented programmes for the employment of disabled and graduates (Pindyuk 2007). Its passive policy was implemented through unemployment benefits. The unemployed were receiving such compensation for the maximum period of six months, and amounted to $60 \%$ of their last net wage, and not exceeding $150 \%$ of minimal wage. In addition to programmes of active labour market policy, the Check Republic effectively implemented programmes of passive policy, because they did not have a negative influence on the duration of unemployment.

Because spending for active labour market policy in NMS-12 is very low, they lag behind the Danish model of flexible security considerably. On the other hand, there are analyses that confirm the efficiency of some programmes (Ederveen and Thiessen 2004). Among NMS-6, Slovenia had the highest percentage of GDP expenditure for active labour market policy in $1998(0.83)$, and was followed by Slovakia (0.32), Poland (0.30), Hungary (0.30), Estonia (0.07) and the Czech Republic (0.05). The highest percentage for GDP expenditure for active labour market policy per percentage of unemployment among NMS-6 in 1998 had Slovenia (0.11), Hungary $(0,036)$, Poland $(0.028)$ and Slovakia (0.026), the lowest the Czech Republic and Estonia (0.007). Despite the fact that Slovenia had the highest percentage among NMS-6, it was still below the EU average (0.16), and lagged considerably behind the Netherlands 
Table 3. Expenditure for Active Labour Market Policy [\% of GDP], (in Brackets: Normalised to the Unemployment Level)

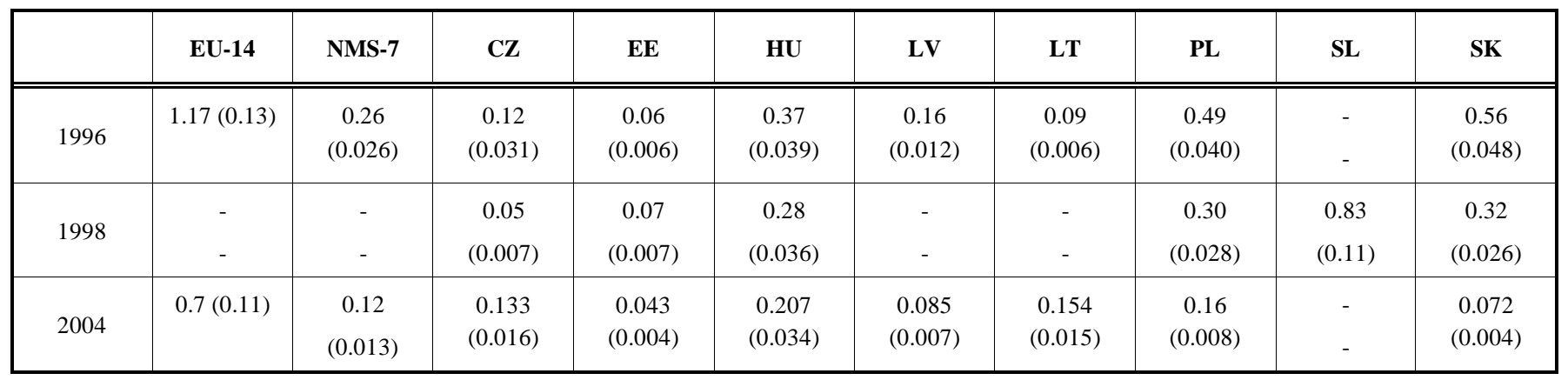

Note: (-) data not available.

Source: Cazes (2002), Anspal and Võrk (2007) and own calculations.

Table 4. Expenditure for Passive Labour Market Policy [\% of GDP], (in Brackets: Normalised to the Unemployment Level)

\begin{tabular}{|c|c|c|c|c|c|c|c|c|c|c|}
\hline & EU-15 & NMS-7 & CZ & EE & HU & LV & LT & PL & SK & SI \\
\hline \hline \multirow{2}{*}{1998} & $\begin{array}{c}2.4 \\
(0.26)\end{array}$ & - & $\begin{array}{c}0.26 \\
(0.05)\end{array}$ & $\begin{array}{c}0.10 \\
(0.036)\end{array}$ & $\begin{array}{c}0.91 \\
(0.01)\end{array}$ & $\begin{array}{c}0.62 \\
(0.036)\end{array}$ & $\begin{array}{c}0.22 \\
(0.043)\end{array}$ & $\begin{array}{c}0.59 \\
(0.017)\end{array}$ & $\begin{array}{c}0.56 \\
(0.058)\end{array}$ & $\begin{array}{c}0.89 \\
(0.044)\end{array}$ \\
\hline \multirow{2}{*}{2004} & $\begin{array}{c}1.94 \\
(0.22)\end{array}$ & - & 0.28 & 0.25 & 0.37 & 0.35 & 0.10 & 0.65 & 0.36 & - \\
$(0.03)$ & $(0.034)$ & $(0.026)$ & $(0.06)$ & $(0.034)$ & $(0.009)$ & $(0.034)$ & $(0.02)$ & - \\
\hline
\end{tabular}

NOTE: (-) data not available.

Source: Cazes (2002), Anspal and Võrk (2007) and own calculations.

(0.55) and Denmark (0.34), which belong to OECD countries with the highest percentage of GDP expenditure aimed at active labour market policy per percentage of unemployment. The OECD average in 1998 was 0.14 .

Between 1996 and 2004, the expenditure from GDP in NMS-7 regarding active labour market policy decreased considerably. The Czech Republic and Lithuania were the only exception. Despite the fact that all NMS implemented different programmes of active labour market policy, the expenditure remained low. At the same time, their growth lagged behind the growth in GDP, which remained considerably high all the time (Anspal and Võrk 2007). Despite high level of unemployment in Poland and Slovakia, they also recorded, as all other NMS, decreased expenditure for active labour market policy (see Table $\mathbf{3})^{2}$.

In addition to expenditure for active labour market policy, expenditure for passive policy also decreased during the period between 1998 and 2004 in NMS-7. The only exception being the Czech Republic, Estonia and Poland. Among NMS-7, the highest percentage for passive labour market policy expenditure in 1998 had Hungary (0.91) and Slovenia (0.89), and the lowest in Estonia (0.10), Latvia (0.22) and the Czech Republic (0.27). All NMS-7 had a lower percentage than the EU-15 average (see Table 4).

The highest percentage of expenditure from GDP for passive labour market policy per percentage of unemployment level can be found in 1998 in NMS-7 in Slovenia (0.11), Poland (0.058) and Slovakia (0.044), the lowest in Estonia (0.01) and Lithuania (0.017). NMS-7 average amounted to 0.05 , in 2004 to 0.03 .

${ }^{2} \mathrm{NMS}$ experiences proved that DFI (direct foreign investment) is extremely important fro the creation of new jobs. Thus, the promotion of DFI can be considered as a measure of active labour market policy.
Before entering the EU, NMS established the majority of labour market institutions, which exist in EU-15 (Ribout $e t$ al. 2003). By doing so, they wanted to increase labour market flexibility and improve adjustment capability of the economy. The majority of states introduced the system of social security in cases of unemployment, which included unemployment benefits. Initially, unemployment benefits were rather high, and had to be lowered later. The reason for this lies in the development of rent seekers and in increased pressure on public finance.

The level of unemployment benefits range in the EU-15 between $50-70 \%$ and are considerably higher than in NMS. The unemployed receive benefits for 6 to 12 months. The amount of unemployment benefits decreased in Lithuania, Hungary, Poland and in Slovakia and remained more or less the same in Lithuania and the Czech Republic. The only exception is Estonia, which increased the amount of unemployment benefits in 2003 by $7 \%$. Despite the increase, the amount remained below the EU average (see Table 5) ${ }^{3}$.

In NMS unemployment benefits are received for a shorter period than in the EMU. Despite higher level of longterm unemployment, unemployment benefits are less progressive in CEE states than in EMU countries. The amount of unemployment benefits ranges between 67 and $130 \%$ of average wage (Boeri and Garibaldi 2005).

In the period of transition, minimum wage in NMS was rather low, and was only partly adapted to price growth level, and if so usually wit a considerable delay. Not so long ago, minimum wage was adapted to the growth of cost of living. In NMS, the value of Kaitz index (which represents the relationship between minimum and average salary) is

\footnotetext{
${ }^{3}$ The correlation between the amount of unemployment benefit and employment security is negative.
} 
Table 5. The Amount of Unemployment Benefits (2003)

\begin{tabular}{|c|c|c|c|c|c|c|c|c|c|c|}
\hline & EU & NMS-8 & CZ & HU & PL & SK & SL & EE & LV & LT \\
\hline \hline first month & 63 & 50 & 50 & 64 & 40 & 60 & 63 & 50 & 50 & 25 \\
\hline 60th month & 37 & 16 & 31 & 24 & 30 & 42 & 0 & 0 & 0 & 0 \\
\hline
\end{tabular}

Source: Babetskii (2005).

Table 6. Minimum Wage (2006, 2nd Half of the Year)

\begin{tabular}{|c|c|c|c|c|c|c|c|c|c|}
\hline & NMS-8 & CZ & HU & PL & SK & SL & EE & LV & LT \\
\hline \hline$€ /$ month & 240.1 & 280.2 & 229.5 & 223.3 & 181.3 & 511.6 & 191.7 & 129.3 & 173.8 \\
\hline
\end{tabular}

Source: Eurostat (2007).

Table 7. The Percentage of Paid Workers, who are Trade Union Members (1995/2002) or are Involved in Collective Bargaining (2002)

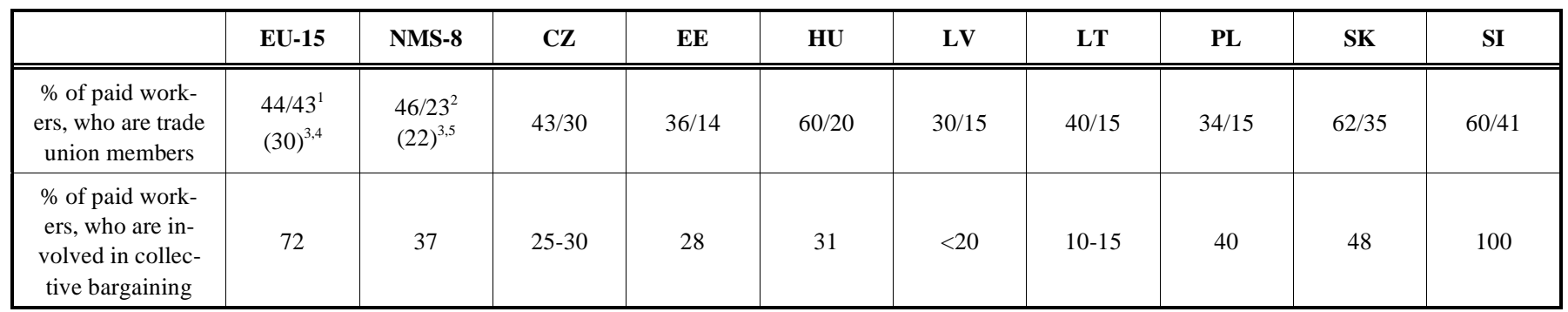

Notes: ${ }^{1}$ Unweighted EU-13 average. ${ }^{2}$ Unweighted NMS-8 average. ${ }^{3}$ Weighted average for $2002 .{ }^{4}$ Data for EU-14. ${ }^{5}$ Data for NMS-9.

Source: Cazes (2002), Anspal and Võrk (2007).

around 30, which is considerably below the EU average (50). The average minimum wage in NMS amounts to one fifth of the average wage in the EMU. Only in Slovenia the average wage can be comparable to the average wages of countries at the bottom of the EMU scale. Among NMS-8, Slovenia had the highest minimum wage in the second part of 2006 $(511,6 €)$, whereas the lowest minimum wage had Latvia (129.3€) (see Table 6).

In NMS, the limitations regarding the salaries in private sector are not binding (Boeri and Garibaldi 2005). The percentage of employees, who are trade union members, is in NMS comparable with the EMU average, whereas the percentage of employees, who are involved in collective bargaining, is not comparable. In NMS, the role of trade unions is weaker than in the EMU and in the EU-15. The percentage of employees, who are trade union members, amounts to 23 $\%$ in NMS-8, and to $43 \%$ in EU-15 (Anspal and Võrk 2007). The percentage of employees, who are involved in collective bargaining, is $37 \%$ in NMS-9, and $72 \%$ in the EU-14. In NMS, collective bargaining is carried out mainly on entrepreneurial level, whereas in the EU-15 they are carried out in the sectoral level. Slovakia and Slovenia are the only exception. The percentage of employees, who are trade union members, has decreased considerably lately (see Table 7). The highest decrease is seen in Baltic countries, Poland, Slovakia, and slightly less in the EU-15. The reason for such decrease is the decrease of the share of processing services and an increase in the share of services, which are less unified $^{4}$.

${ }^{4}$ Privatisation of state companies, higher level of unemployment and increased number of small and medium-sized enterprises are key reasons for the decrease of unification in iondividual sectors

\section{Employment Security Index (Index EPL)}

During the previous socio-economic system employment security was extremely high in the majority of NMS-12. The basic feature of labour markets was high employment growth. During the 70 s of the previous century the employment growth level in Slovenia increased by 3.8\%, which was the consequence of the then socio-economic system, which allowed for permanent retention of jobs. After 1973, when the opportunities to get employment abroad decreased and when, after 1980, economic growth in the ex-Yugoslavia begun to stagnate, the autonomous employment growth caused the growth of disguised unemployment. Due to the economic crisis the annual employment growth level decreased to $0.3 \%$. After 1987, registered unemployment also started to increase. Because of economic restructuring and higher efficiency in the distribution of production factors, employment security decreased in the majority of NMS-12 after 1990 (Cazes 2002).

In the majority of NMS EPL index has decreased form the 90s of the previous century to 2004. In 2003, the Czech Republic and Hungary had the lowest EPL index among the NMS-12, which have the most flexible working legislation. They were followed by Slovakia, Poland and Lithuania, and Latvia, Estonia and Slovenia, which have similar EPL index as the EU-14 states (Anspal and Võrk 2007). Bulgaria, Estonia, Lithuania and Romania have strict employment legislation, especially in the area of collective redundancies (see Table 8). Baltic states have a higher EPL index and lower amounts of unemployment benefits, whereas Central European states have a more flexible legislation and higher amounts of unemployment benefits. 
Table 8. EPL Index ${ }^{1}$ za NMS-9 [1-6] (end of 90s of 20th cent./2002/2003/2004)

\begin{tabular}{|c|c|c|c|c|}
\hline & Index EPL (1-6) & \multicolumn{3}{|c|}{ EPL index components } \\
\hline The Czech Republic & $2.2 / 2.1 / 1.9 / 2.0$ & $3.0 / 2.8 / 3.3 / 3.3$ & $0.5 / 0.5 / 0.5 / 0.5$ & $3.2 / 4.3 / 2.1 / 2.6$ \\
\hline Estonia & $2.4 / 2.6 / 2.6 / 2.3$ & $2.9 / 3.1 / 3.1 / 2.7$ & $1.7 / 1.4 / 1.4 / 1.3$ & $2.9 / 4.1 / 4.5 / 4.0$ \\
\hline Hungary & 1.8/1.7/1.7/1.6 & $2.1 / 2.1 / 1.9 / 2.2$ & $1.2 / 0.6 / 1.1 / 0.4$ & $2.5 / 3.4 / 2.9 / 3.4$ \\
\hline Poland & $2.0 / 2.0 / 2.1 / 2.2$ & $2.3 / 2.2 / 2.2 / 2.0$ & $1.4 / 1.0 / 1.3 / 2.0$ & $2.7 / 3.9 / 4.1 / 3.5$ \\
\hline Romania & $-/ /-/ / 2.8$ & $-/-/-/ 1.7$ & $-/-/-/ 3.0$ & $-/ /-/ / 4.8$ \\
\hline Slovakia & $2.3 / 2.4 / 2.0 / 1.7$ & $2.6 / 2.6 / 3.5 / 2.7$ & $2.0 / 1.4 / 0.4 / 0.3$ & $2.4 / 4.4 / 2.5 / 3.0$ \\
\hline EU average & $2.4 / 2.4 /-/-$ & 2.4/2.4/-/- & $-/ 2.1 /-/-$ & $-/ 3.2 /-/-$ \\
\hline
\end{tabular}

Note: ${ }^{1}$ Employment Protection Legislation Index. EPL index is calculated as weighted average of 22 indicators, which are regarding to procedures, expenses, limitations and conditions regarding the termination of employment contract. The value of EPL index can be 1-6: countries with the most flexible legislation have index close to 1, countries with the least flexible legislation have index close 6. (-) data not available

Source: Rutkowski (2003), Matković and Biondić (2003), Mitcevska (2003), Tonin (2004) and Anspal and Võrk (2007).

With regard to security indicators of part-time employment, convergence was noticed among the EU-14 states in the period between 1990 and 2003. In Southern European countries, the flexibility of labour legislation increased, whereas in Anglo-Saxon it decreased. This is also one of the reasons why the Czech Republic, Slovakia and Slovenia are getting closer to Great Britain and Ireland with regard to part-time employment security indicators. In 2003, Slovakia liberalised labour legislation regarding collective redundancies and full-time employment. The most important reforms in the labour market were carried out in Slovenia, which had an influence on the lowering of EPL index in 2003 (Kajzer 2005). Slovenia does not lag behind the Western European countries with regard to flexible employment practices. Among all newly signed contracts $70 \%$ were part-time contracts. Despite reforms Slovenia still has the most restrictive labour legislation among CEE-8 countries (Gwartney et al. 2005).

\section{Full-Time Employment}

In the Czech Republic and Bulgaria an employer does not need to give a valid reason in order to give notice. On the other hand, it is obligatory in Slovenia to give a valid reason for the termination of employment. Slovenian legislation states the following among valid reasons for the termination of employment: business reason, the reason of incapacity and fault reason. The Act also states unfounded reasons for the termination of an employment contract: temporary absence from work due to disease or injury or due to parental leave, trade union membership and participation in trade union activities (including participation in a strike). Exercising workers' rights against an employer is also stated in the Act. Before the employment termination, the employer has to carry out certain procedural obligations - the employer must in writing call the worker's attention to the possibility of employment termination. The employer must provide the worker an opportunity to defend himself (this is also the case in Hungary and Croatia). If thus requested by the worker, the employer must inform in writing the trade union. The trade union may give its opinion within eight days. If the trade union opposes the termination, the termination of the contract is not effective until the expiration of the term for arbitration and/or judicial protection. Because the termination of contract is not effective, the worker remains employed until the process is concluded. This is an extremely important protection. In Estonia, the employer also has to inform trade unions about the employment termination, whereas in Ukraine, the employer only has to do so in cases when the worker has not been offered another job or in cases when a worker does not want to accept the offered job (Tonin 2005).

Trade Unions also have an important role in Croatia, the Czech Republic and in Lithuania, as well as in Slovakia, where employers have to negotiate the employment termination with the Trade Union (which is similar to the situation in Poland).

The amount of unemployment benefit depends on the reason for the employment termination in Bulgaria, Estonia, the Czech Republic and in Slovakia. In Slovenia, the amount depends on years of service, if the employment termination is due to business reasons (because of economic, technological, structural, organisational and other reasons).

In some NMS-12 states (e.g. in the Czech Republic and in Lithuania) age, years of service, the number of dependents, etc have to be considered before the employment termination. In Hungary, Poland and Bulgaria employers have to offer another job before the employment termination (Tonin 2005). In Estonia, workers are treated preferentially with regard to their trade union activities and skills, whereas in some NMS countries social components are taken into account. 
Table 9. Percentage of Part-Time Employees (2005), NMS-12

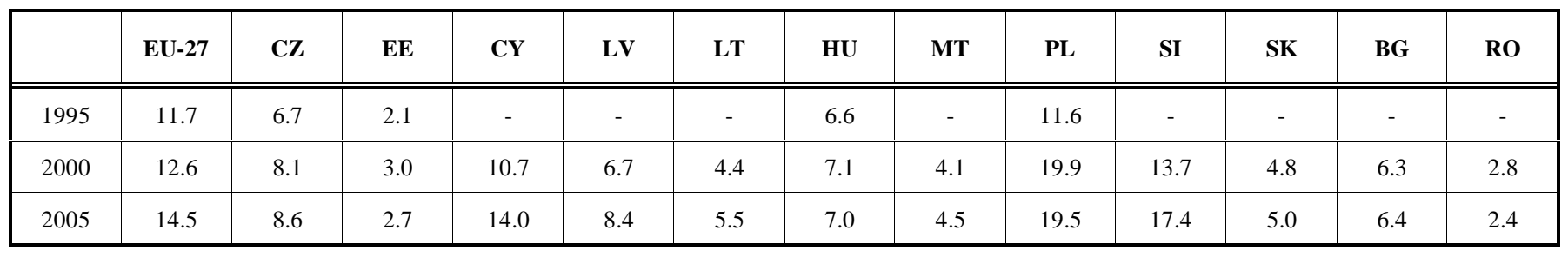

Note: (-) data not available.

Source: Vermeylen and Hurley (2007).

In the case of unfounded reasons for employment termination the employer is obliged to pay the worker the compensation for any loss of income and penal provisions. This does not hold true for Croatia, Estonia and Slovenia. Slovenian legislation does not directly determine the amount of compensation for the loss of income and penal provisions, whereas in Estonia and Bulgaria the legislation determines that the compensation for the loss of income should amount to six last average salaries. In Croatia the amount of compensation depends on the duration of the last signed employment contract and on the age of the worker. Frequently, the amount of compensation for loss of income also depends on the employer who may or may not offer the worker who has been previously made redundant to conclude a new employment contract (Tonin 2005).

\section{Part-Time Employment}

Part-time employment depends on objective circumstances, among which the following should be mentioned: temporary increased amount of work, seasonal work, project work, employment of a foreigner, employment of a manager, etc ${ }^{5}$. In Hungary, Slovakia and Poland there are no limitations regarding the reasons for concluding part-time employment contracts. On the other hand, the conclusion of employment contract outside objective reasons differs among the states considerably due to different legislation. Croatia and Ukraine have limited the use of part-time contracts to objective, whereas Slovenia, Estonia and Lithuania also state certain special circumstances. Slovenian legislation states, for instance, that the conclusion of part-time employment contracts is possible for jobs that are temporary in their nature.

In Bulgaria, part-time employment contracts can be concluded for the period not longer than three years, and cannot, in some cases, be prolonged. There are also limitations regarding minimum duration. Such system was also introduced in 2004 by Lithuania, Estonia and Poland, whereas Hungary, Croatia and the Czech Republic introduced limitations regarding contract chaining and the total duration of such employment. Due to the problem of contract chaining in Slovenia, the duration of such employment was limited to the maximum of two years. It is not allowed, according to the legislation, to sign one or more part-time employment contracts with the same worker and for the same work for more than two years (for three years during the transitional period). After this period of time, a full-time employment contract should be signed. If the fixed-term employment contract has been concluded contrary to law or if the worker

${ }^{5}$ Objective circumstances are defined differently in different countries. continues to work even after the period for which he had concluded the employment contract, it shall be assumed that the worker had concluded an employment contract for an indefinite period of time (see Table 9).

Slovenian legislation also determines part-time employment through Employment Services. Such part-time employment contracts are of temporary nature and can only last up to one year (the same situation is in Croatia and the Czech Republic, whereas Hungary and Slovakia do not limit the duration of such contracts). During the time, when the worker is employed, he receives a full payment, whereas during the time, when the worker does not work, the wage cannot be lower than $70 \%$ of minimum wage, the risk is being carried by the Employment Service. In some cases, the legislation does not allow such employment practices: in cases when workers employed with the user are on strike, in cases when the user has during the period of the past 12 months terminated employment contracts to a large number of workers employed (full-time) with him and in cases of workplaces that shows that workers are exposed to dangers and risks. In Poland, this employment practice can be used only within objective circumstances.

In Bulgaria, the employer can sign a part-time contract with the worker only in cases stipulated in the law, whereas Estonia and Poland do not stipulate any limitations. In the Czech Republic, the employer is not allowed to sign a parttime contract with the candidate, who completed the probation, secondary school or a faculty period less than two years ago, and who acquired suitable qualifications for certain jobs, except if the candidate is willing to sign such a contract.

In Hungary, the conditions for chaining part-time contracts have become stricter lately. The same has also been done in Poland, which, at the same time, introduced very strict legislation regarding part-time employment through Employment Services (Anspal and Võrk 2007). In Bulgaria, Estonia and in the Czech Republic, chaining of part-time employment contracts is not limited in any way. This is not the case in Poland, where the employer and worker can only sign a part-time contract twice, whereas the third contract automatically becomes a full-time employment contract. In the Czech Republic, Poland and in Estonia, the labour legislation does not limit the cumulative length of part-time employment, which, on the other hand, is not the case in Bulgaria.

In Bulgaria, Estonia, the Czech Republic and in Poland labour legislation does not govern part-time employment through Employment Services. 


\section{Collective Redundancies}

Laying off of workers is considered collective redundancies if an employer makes workers redundant in the following way: within the period of 30 days at least 10 workers with the employer employing more than 20 and less than 100 workers are made redundant, at least $10 \%$ of workers (with the employer employing at least 100 workers, and less than 300 workers) or at least 30 workers with the employer employing 300 or more workers. This definition differs from one state to another (say in the Czech Republic, Hungary, Poland, Estonia and Latvia). In Bulgaria, collective redundancies is mentioned in the Employment Act, but not precisely defined (the same holds true for the Russian Federation). In Estonia and Poland, there is no legal act, which would regulate collective redundancies.

\section{SOCIOLOGICAL ASPECT}

Interaction between religion and work, religion and work ethics/creativity is not something that could be precisely determined or even measured. Only general evaluations are possible. It can be said that the capitalism in Northern and Western Europe exceeded the dynamics and successfulness of capitalism in Southern and Eastern Europe, which is predominantly Catholic. In addition, it can be argued that the Western and Northern Europe, both predominantly protestant and catholic Europe were more developmentally successful and productive than Eastern and Southeastern, predominantly Orthodox societies. Last but not least, it can be said that the Christian West is more rationally creative than Islamic societies in the Near East and that the members of Jewish community manifested considerably more commitment to work, success, rational creativity than Islamic and Catholic societies, etc.

These findings are relative and should be critically examined from the point of view of concrete historical, cultural and political situations, and individual communities, nations, states, religions, social classes. Various deviations are possible.

With regard to piety and lack of piety in the East of Europe, the situation is even more complicated than in the West, mainly due to turbulent social and historical events, both in the past and recent history. The situation is remarkably diverse. Poland, a predominantly Catholic country, was often at war with aggressors from the West, East and South, occasionally even wiped off the map. Latvia, Lithuania and Estonia suffered similar fate, and, depending on cultural and political circumstances, took over Catholic, Lutheran or Orthodox religion. In Serbia, Ukraine, Belarus, Russia, Romania, Bulgaria and Macedonia the prevailing religion Orthodoxy. Rusyns are so Eastern Catholics. Turks, Albanians, Tatars and certain ethnic groups on the Balkans, the Ural and the Caucasus Mountains are mainly Muslims. Jews and Romany people, two dispersed nations, adapt to the sociopolitical and cultural conditions in different environments: devout Jews stick to their traditional religion; Romany people usually adopt the predominant religion of the country, while often preserving the respect of ancestors. It is often believed that Jews are very entrepreneurial and work motivated, which is in accord with their religion. On the other hand, the existence and mentality of Romany people are marked with such way of life, which does not value systematic, long-term economic activities.

For decade, Eastern Europeans (in some countries for seventy years, in others slightly less) were deprived of religious activities. Authoritarian communist system in the Soviet Union and in countries of the so-called national democracies led to shocks and crises in religious institutions and in the life of believers. Such unnatural and inhuman conditions could not have a positive effect on work ethic and creativity, especially if they were connected with economical and political so se retaliatory measures (coercive acts of collective faming (kolhoz), agricultural cooperatives, etc.). Persecutions and other methods of coercive atheisation resulted in people losing faith on the one side, or caused the formation of sects on the other side, which proved to be rather resistant to oppression. Sociologists described three types of atheisation: incidental, spontaneous and socio-convertive (Ćimić, 1971, 199-200).

Due to the relationship towards religion and religious institutions, there was little scientific research carried out about religions in Eastern Europe. Essentially, religions were dealt with in an ideological and political way in the sense of atheistic propaganda. Political police controlled religious life and acted in the service of repressive executive and judicial authorities.

It can be seen from the above that it is almost impossible to arrive at an objective judgment about the influence of religion on work and economic activities in nations in this part of Europe. Through repression, traditional values were pushed aside, became deformed or even eliminated. In many cases non-values appeared instead of values. Sound answers about how certain religions influence on work and economic behaviour of people can only be reached through interdisciplinary economic, religious, moral, and sociological research.

\section{CONCLUSION}

The choice of a particular form of flexicurity depends primarily on historical development of labour markets, collective agreements and the role of government in these, as well as on basic considerations of social and labour policy, values and religion.

Protestants were highly attracted vocational training, they climbed the corporate ladder and often took leading managerial positions. They were extremely entrepreneurial, which Catholics usually lacked. On the other hand, Protestants prospered and achieved enviable financial positions. Different religions in their moral/theological and socioethical conceptions deal with work, creativity and economic behaviour in rather different ways, which influences the life and behaviour of believers. In general terms it is possible to ascertain that some of these concepts are more work-related, productive and motivating, practical in its secular everyday meaning, whereas others favours passive attitudes and contemplative spirituality.

Labour market flexibility ensures labour cost adjustments and the reduction of the number of unemployed workers. This has been proved by the experiences of countries with a high labour market flexibility and low employment security. On the other hand, countries with high employment security 
and poor labour market flexibility have a higher level of unemployment. Labour market flexibility has an important impact on the supply of workforce, because the workforce can, under the active labour market policy, education and training adapt to the market demand. The latter can also represent a reduction in social security entitlements for the employees. Therefore, it is necessary to choose such a combination of economic policy measures in the NMS-12 that will increase labour market flexibility on one side and retain a high level of social security on the other side.

Experiences of some NMS show that it is necessary to judge the appropriateness of individual forms of labour market flexibility and security both from the point of view of competitiveness of the economy as a whole and social security of employees. The system of flexicurity requires a certain degree of »maturity « of the society and social partners, trust during negotiations and a certain negotiation culture, needed for the harmonisation of different interests among the participants (employers, employees, government). Values, ethics, competences and the attitude of workers towards success should also be taken into account. Imposing different forms of flexicurity on the environment with rigid labour market and poorly developed labour legislation can lead to unfavourable effects, threaten social security of employees, lead to abuse of the system, increase expenses for active and passive labour market policy and question the soundness of the reforms.

An important question is also to what extent the success of different forms of flexicurity depends on economic conditions and labour market characteristics. The advantages of individual forms are, above all, shown during the period of lower economic growth, when employees become increasingly resistant to more flexible forms of employment, and when the demand for more security is on the increase. Experiences of Western European countries proved that favourable trends on the labour market during favourable economic conditions are mainly due to favourable economic trends and not more flexible employment practices. This, of course, did not bring to light all disadvantages of individual types of flexicurity.

High administrative expenses should also be mentioned among the disadvantages of flexicurity (expenses related to employment brokerage, ensuring unemployment benefits, etc.), which may appear in the case of low efficiency of the public sector. Therefore it is necessary to determine the expenses and benefits stemming from the introduction of different types of flexicurity. With frequent job changes the question may be raised about the motivation of the employers to finance education and training of employees with atypical employment contracts and what level of uncertainty is acceptable for the employees.

\section{REFERENCES}

Andersen, M., Torben, \& Svarer, M. (2005). The Danish labour market from excess to shortage. In Structural unemployment in Western Europe: reasons and remedies, M. Werding (Ed.), MIT Press, Cambridge.

Anspal, S., \& Võrk, A. (2007). Labour Market Institutions and Productivity in the New EU Member States. PRAXIS Working Paper, no. 27. Tallinn: PRAXIS Center for Policy Studies.

Auer, P., \& Cazes, S. (2000). Stable or unstable jobs: untangling and interpreting the evidence in industrialized countries. Geneve: International Labour Organization.
Babetskii, I. (2005). Aggregate wage flexibility in selected New EU Member States. In CESifo Working Paper Series, no. 14. München: CESifo.

Boeri, T., \& Flinn, C.J. (1999). Returns to Mobility in the Transition to a Market Economy. Journal of Comparative Economics, 27(1), pp. 4-32.

Boeri, T., \& Lehmann, H. (1999). Unemployment and Labour Market Policies in Transition Economics. Journal of Comparative Economics, 27(1), pp. 1-4.

Boeri, T., \& Garibaldi, P. (2005). Are Labour Markets in the New Member States Sufficiently Flexible for the EMU? Retreived November 16 2007 , http://www.carloalberto.org/people/garibaldi/doc/labormkts.pdf

Bredgaard, T., Larsen, F., \& Madsen, P.K. (2005). The flexible dannish labour market - review. Aalborg University, Aalborg.

Cazes, S. (2002). Do labour market institutions matter in transition economies? An analysis of labour market flexibility in the late nineties. In Discussion paper, no. 140. Geneve: International Institute for Labour Studies.

Ćimić, E. (1971). Drama ateizacije (Drama of ateism). Sarajevo: Zavod za izdavanje udžbenika.

Clasen, J., Kvist, J., \& van Oorschot, W. (2001). On condition of work: increasing work requirements in unemployment compensation schemes. In Nordic Welfare States in the European Context, M. Kautto, J. Frit-Zell, B. Hvinden, J. Kvist, \& H. Uusitalo (Eds.): London: Routledge.

Đurić, M. (1964). Sociologija Maxa Webera (Sociology of Max Weber). Zagreb: $\mathrm{MH}$

Fernández-Armesto, F. (1997). Narodi Evrope - The Times (Nations of Europe). Zagreb: Naklada Zadro.

Gwartney, J., \& Lawson, R. (2005). Economic freedom of the world: 2005 annual report. Vancouver: The Frase Institue.

Izetbegović, A. (1990). Islamska deklaracija (Islamic declaration). Sarajevo: Zavod za izdavanje udžbenika.

Juhant, J., \& Valenčič, R. (1994). In Družbeni nauk Cerkve (Social doctrine of church), J. Juhant, \& R. Valenčič, (Eds.). Celje: MD.

Kajzer, A. (2005). Labour market flexibility. Slovenian Economic Mirror 11(3), pp. 13-17.

Kluve, J., Lehmann, H., \& Schmidt, C.M. (1999). Active Labor Market Policies in Poland: Human Capital Enhancement, Stigmatization, or Benefit Churning? Journal of Comparative Economics, 27(1), pp. 61-89.

Kluwe, J., Lehmann, H., \& Schmidt, C.M. (1999). Active labour market policies in Poland, human capital and enhancement, stigmatisation, or benefit churning? Journal of Comparative Economics, 27(1), pp. 61-89.

Kovačič-Peršin, P., Milošević, Z. and Vakanjac, M. (2005). Pravoslavje in globalizacija (Religion and globalization), no.171-172-173. Ljubljana: FDV

Lubyova, M., \& van Ours, J.C. (1999). Effects of Active Labour Market Programs on the Transition Rate from Unemployment into Regular Jobs in the Slovak Republic. Journal of Comparative Economics, 27(1), pp. 90-112.

Madsen, P.K. (1999). Denmark: flexibilty, security and labour market success. In Employment and Training Papers. Geneve: International Labour Organization.

Madsen, P.K. (2002). Employment protectionism and labour market policy: trade-offs or complementaries: Country study - Denmark. Geneve: International Labour Organization.

Marx, K. and Engels, F. (1969). Izbrana dela (Selected papers). Ljubljana: $\mathrm{CZ}$

Matković, T., \& Biondić, I. (2003). Reforma Zakona o radu i promjena indeksa zakonske zaštite zaposlenja (Reforms of the Law on employment and security). Financijska teorija i praksa, 27(4), pp. 515529.

Mitcevska, M. (2003). Unemployment and labour market regidities in South-East Europe. In Workshop Enterprise Development, The Informal Economy and Labour Markets in South-East Europe. Vienna: November 28-29, 2003.

Parent-Thirion, A., Macías, E.F., Hurley, J., \& Vermeylen, G. (2007). Fourth European working conditions survey. Dublin: European Fundation for the Improvement of Living and Working conditions.

Pavičević, V. (1980). Sociologija religije (Sociology of religion). Beograd: BIGZ.

Pindyuk, O. (2007). Trade Restructuring in the CIS: Lessons of the NMS and Policy Recommendations. INDENIUS Papers. 
Riboud, M., Jaureguli, C.S.C., \& Sanches-Paramo, C. (2002). Eurosclerosis matter? Institutional reform and labour market performance Central and Eastern European countries. In Labour, employment and social policies in the EU enlargement process, B. Funck In L. Pizzati (Eds.). Washington: World Bank.

Rutkowski, J. (2003). Does strict employment protection discourage job creation? Evidence from Croatia? World Bank Policy Research Working Paper, no. 4104. Washington, World Bank.

Seifert, H., \& Massa-Wirth, H. (2005). Pacts for employment and competitiveness in Germany. Industrial Relations Journal, 36(2), pp. 2436.

Tonin, M. (2005). Updated employment protection legislation indicators for Centrala and Eastern European Countries. Stockholm: University Stockholm.

Truhlar, V.K. (1967). Pokoncilski katoliški etos (Postcouncil chatolic ethos). Celje: MD.

Turner, S. (2000). The Cambrige Companion to Weber. Cambridge: University Press.

van Oorschot, W. (2001). Activation \& flexicurity policies in the Netherlands. In Work, welfare and citizenship. Tilburg: University, Department of sociology, Tilburg.
Vermeylen, G. \& Hurley, J. (2007). Varieties of flexicurity: reflections on key elements of flexibility and security. Dublin: European Fundation for the Improvement of Living and Working conditions.

Vielle, P. \& Waltherty, P. (2007). Attractive work places for all, a contribution of Lisbon strategy at company levels, company examples, European Fundation for the Improvement of Living and Working conditions, Luksemburg.

Weber, M. 1968. Protestantska etika i duh kapitalizma (Protestant ethic and spirit of capitalization). Sarajevo: Veselin Masleša.

Weber, M. (2000). Sociologija religije (Sociology of religion). Zagreb: Kruzak.

Wilthagen, T. \& Tros, F. (2004). The concept of flexicurity: a new approach to regulating employment and labour markets. Transfer - European Review of Labour and Research, 10(2), pp. 166-187.

Wilthagen, T. \& van Velzen, M. (2005). The road towards adaptability, flexibility and security. Tilburg: University Tilburg.

Zawadski, K. (2005). Transitional Labor Markets in a Transitional Economy. Could They Work? Example of Poland. Poznan University, Poznan. 
Appendix 1. Some characteristics of Labour Market in NMS-12

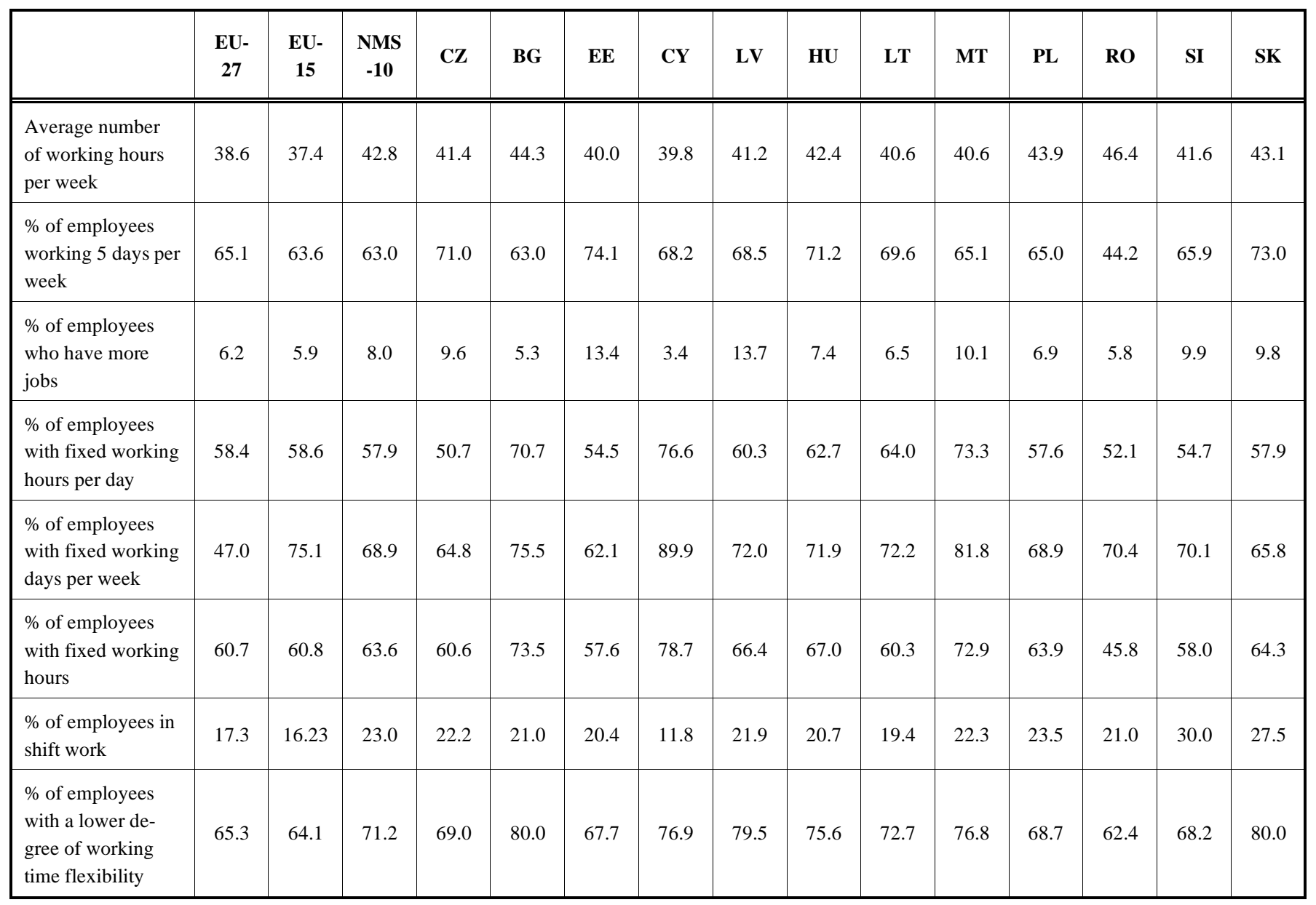

Source: Parent-Thirion et al. (2007). 